\title{
REVIIEW
}

\section{A MAN OF MANY PARTS}

\author{
[Review by Janet West* of Tom and Cordelia Stamp's William Scoresby, Arctic Scientist. Whitby, \\ Caedmon of Whitby Press, 1976, 253 p, illus. $£^{3.50}$.]
}

William Scoresby first went to the Arctic at the age of 10 , with his father's connivance. He hid aboard his father's whaler, the Dundee. 'Mother... suffered greatly in my absence. On the arrival of the pilot boat with the intelligence of my elopement, she could not credit the information ... and was overwhelmed with grief.'

Tom and Cordelia Stamp's interesting biography details Scoresby's extraordinarily varied career in which observation and experiment were dominant features. Much of the source material is new, derived from the thousands of papers which Scoresby bequeathed to the Whitby Literary and Philosophical Society. The charm of this book lies in the incorporation, verbatim, of many letters passing between Scoresby, his family, friends and associates; they illuminate the people and the period as no transcription could. With Scoresby we travel widely, attend university, meet the famous, suffer bereavement, move house, teach the children, give lectures, attend banquets (menus provided) and are disgusted by the eating habits on American steamboats. The continuity is maintained by a well written narrative and the illustrations, mostly from contemporary engravings, are of reasonable quality. The date and Scoresby's age are given at the head of each page.

William Scoresby (1789-1857) was the son of a successful Whitby whaling captain. Having survived his first Arctic experience he was apprenticed to his father at 13, and gained command of the Resolution at 21 , eventually becoming a successful man with a substantial income. Through his father he was introduced to Sir Joseph Banks, which led to a lifelong association with many men eminent in the developing sciences in Britain and abroad.

In 1820 , Scoresby spent his first summer ashore for 20 years, preparing his remarkable book An account of the Arctic regions. The book, still a major reference work on the Arctic, was internationally acclaimed by scientists. Scoresby made many ingenious devices on board ship; notable was his Marine Diver which could sample to $2400 \mathrm{~m}$. Problems of navigation were always his concern, especially compass error. To improve the power and stability of the compass he invented the laminated compass needle, which was eventually adopted by the Admiralty-without acknowledgement. (The powerful magnets he made at sea, one still holding its $14 \mathrm{lb}$ [6 kg] weight, are on view in Whitby Museum together with the laminated needles, Scoresby's paintings and drawings, and other treasures.) His pioneer work in Arctic biology, meteorology and oceanography was recognized by his election to the Royal Society in 1825 .

The authors rightly campaign for our wider recognition of Scoresby's achievements. He was perhaps unfortunate in working when the most spectacular advances were being made in the physical sciences, and the professional was replacing the amateur scientist. He lived at a time when exploration was the monopoly of the Navy. However, a greater man than John Barrow would have acknowledged Scoresby's experience, and his treatment by the Board of Longitude was sadly in character: had they not taken 40 years to reward Harrison for his chronometer?

One feels, however, that at times Scoresby was difficult to deal with. In 1823 he entered the Church, eventually becoming Vicar of Bradford in 1839. It was a difficult parish, but perhaps some of his problems might have been avoided had he been less concerned with the rights rather than the spirit of his calling. Nevertheless, we picture a dedicated man, devoted to his family and optimistic in his belief that situations can be improved. While there are a few errors (John Ross's expedition was in 1818, not 1819, and the Manhattan a tanker, not an icebreaker), and a more comprehensive index would have been welcome, this is a warm and balanced work of scholarship.

* The Open University, Hills Road, Cambridge. 